\title{
THE FIRST DECADE OF THE SHERMAN ACT: EARLY ADMINISTRATION*
}

\author{
WILLIAM LETWIN†
}

WHEN the Sherman Act was passed in 1890, it was taken to mean the end of trusts. Once it became apparent, however, that the mere enrollment of the act in the statute books would not do away with every activity that might be called a trust or be condemned as monopolistic behavior, critics began to search for a scapegoat. Common complaints were that Congress had deliberately passed a mock law, too weak and badly worded to accomplish anything; and that the courts' antiquated ideas prevented them from countenancing or even understanding the purpase of the act. Other critics rejected these explanations, however, and maintained that the fault lay in the administration of the act. Thus, as early as 1892, Senator Edmunds, a principal author of the statute, remarked: "the law is all right, the courts are all right, and the people are all right. Let the officers charged with the enforcement of the law do their full duty and Trusts and combinations will go to pieces as quickly as they sprang into existence."1 The critics who have adopted Senator Edmunds' view speak as though all statutes work automatically, halted only by the sabotage of indifferent or hostile prosecutors. This is far from true of the Sherman Act. Many of the difficulties of enforcing the antitrust law were certainly not unique. The most common criticisms of early Sherman Act administration ignore the fact that the implementation of any law, far from being a matter of "full duty" or even plain duty, often requires delicate discrimination.

Even ancient and familiar laws, like those proscribing murder, do not enforce themselves. A conspicuous dead body will command the attention of public officials; but the public prosecutor must decide how much effort should be spent on ferreting out hidden corpses. Once a crime is known, he must decide what resources should be allocated to discovering evidence against the criminal. And finally, he must determine whether the particular sort of killing is prohibited by the murder laws as they are then interpreted, or, if not, whether he can persuade a judge to read the laws to cover the case. Although the prosecutor must protect the public from crime, he must also respect the right of citizens to be free from wanton prosecution when there is no likelihood of their being convicted. Nor can he escape the responsibility of his role in

*The first of two articles by the author, dealing with the early history of the Sherman Act. The second-concerning initial attempts at judicial construction-will appear in a subsequent issue of volume 68 .

$\uparrow$ Associate Professor of Industrial History, M.I.T. School of Industrial Management. Formerly, Research Associate in the University of Chicago Law School's Antitrust Project, under whose auspices the research for this Article was undertaken.

1. N.Y. Times, Nov, 25,1892 , p. 4 , col. 2. 
deciding whether a law should be extended to a new class of case, for the courts can only act upon cases laid before them. Thus, no prosecutor can avoid acting as a policy maker. He affects the law no matter how he chooses to execute it.

The breadth of his discretion allows a public prosecutor, and particularly the Attorney General of the United States, to adopt a theory of his office anywhere between two extremes. At the least, he must attack some abuses presumed to be violations, and he may select those that the public considers outrageous, those that he estimates would best serve to warn other violators, or those where evidence is readily available and victory most certain. The opposite limit is harder to define. It seems clear, however, that a prosecutor who sought to stretch statutes beyond their ordinary meaning in order to prohibit the widest range of conduct, or to prosecute every person against whom a shred of evidence could be found, would be weakening the presumption of innocence and overly extending the power of government. Equipped with enough resources, such an officer might turn any modern society into a police state, without involking any authority beyond the already existing statutes.

Exactly where between these extremes of enforcement policy a particular Attorney General will choose to stand depends on his estimate of the capacities of various statutes and the policies they tend to serve. He may feel that some laws are dead, feeble, or harmful, and may therefore plan to leave them unused, unless or until the public cries out for their enforcement. He may believe that other statutes are not yet exerting the force they should have and may begin a campaign to invigorate them. Guiding the prosecutor's actions, in part, will be his convictions about what laws should do. Clearly, his private opinion that a law is undesirable would not justify a categorical refusal to enforce, any more than the opposite view would warrant his concentrating all efforts on catching anything that might be termed a violation of the statute.

Since no one will believe that all existing statutes are equally necessary, useful or wise, and since the Attorney General must exercise discretion in deciding which laws he will enforce and to what extent, his views on the quality of the laws do, and should, affect the exercise of his office. Moreover, since he serves not only as the Government's chief attorney but also as a cabinet member, and as such is the representative of a particular administration, the policy of his office may properly be influenced by his party's standards of what is wise legislation and enforcement policy. To be sure, our framework of government contains no provision for rewriting the statutes as each new administration takes office. But if it were not intended that law enforcement should be subject to some political control, it would have been more reasonable to provide that the Attorney General should be a civil servant with life tenure, rather than a political appointee.

There are consequently two distinct grounds on which the execution of a law can be criticized. The prosecutor may be attacked for having willfully misused his office, either to protect criminals or to oppress the innocent. Or he may be criticized for being more (or less) energetic than the public interest 
requires. The first line of censure questions the prosecutor's good faith; the second, his political wisdom; and, though both attacks may at times be justified, they should be recognized as distinct. Reviews of the early administration of the Sherman Act have generally failed in this regard. The critics notice only that the Attorneys General between 1890 and 1901 were less vigorous in executing the Sherman Act than its most fervent advocates might have wished, and they forget the wide range of honest choice that was open to the federal prosecutors of this period in determining the best way to implement the new antitrust law. These critics also do not take into account the more material circumstances under which the Attorneys General had to work.

\section{Administrative Difficulties Facing the Attorney Geineral}

Anyone accustomed to the spending habits of mid-twentieth-century government must be astonished by the poverty of the Department of Justice in the 1890's. However eager an Attorney General might have been to prosecute antitrust cases, he would have been seriously hampered by the resources at his command. Congress had supplied no special funds for enforcing the Sherman Act, and even before antitrust work was added to his duties, the chief prosecutor was complaining that his forces were too small and cramped for want of money. In 1890, the Department of Justice occupied the upper stories of a bank building, employed eighty persons of whom eighteen were lawyers, and had an increasingly heavy load of routine work. Cases before the Supreme Court-the responsibility of the Solicitor General and one of the assistant attorneys general-had risen in number from an average of 60 during each of the previous ten years to 180 in 1890 . Suits in the Court of Claims had increased almost twenty-fold since 1880, but the Assistant Attorney General in charge had no more help than before. ${ }^{2}$ Aiding him in his principal work were six attorneys, each of whom had to prepare about ten cases every month; he directed, besides, one attorney and two law clerks who dealt exclusively with French spoilation claims. In 1890 this group of ten lawyers was responsible for the 13,000 claims then pending against the Government. The remaining Assistant Attorney General worked chiefly on Indian depredation cases-clains for damages done in the period between the Creek War of 1836 and the Sioux uprising of 1890 . Over 5,000 such petitions had been submitted during the first six months following their congressional authorization, and many more were expected. The officer in charge complained that "there are only two regular employés in the office . . . and it is impossible with this force to keep up the dockets, records, and history of the cases, as they are daily being filed, as they should be kept for the proper administration of my office, to say nothing of the very important work of examining witnesses and preparation of cases for trial." A Another official reported that "it is physically impossible

2. 1891 AtT'y Gen. Ann. Rep. 3, 11.

3. Id. at 15 . 
that the force assigned by the present law will be able to adequately transact the business...."4

The Attorney General's annual accounting indicates the care with which every penny was doled out. When Solicitor General William Howard Taft traveled on government business, his omnibus fares, twenty-five cents, were carefully entered. Another twenty-five cent amount-for stationery purchased by an employee-was recorded as reimbursed, the employee having certified that the item was necessary because the stationery "furnished by the Department was not properly ruled, and could not be used for the purpose."s Eight cents spent for mailing a deposition to a witness was not reimbursed, perhaps because the acting commissioner who claimed it had not submitted a voucher. ${ }^{6}$ The costs of "1 Yale Key," $\$ 0.36$, of one and one half dozen pins, $\$ 0.83$, of "1 fitch, round," $\$ 0.10$, found their appointed places, as did the less plausible item "500 clock dials, $\$ 2.50 . " 7$ Nothing was spent at mere discretion, and in order to repair a federal jail, defective among other things in that "the lever that locks one tier of cell doors [was] out of order and useless," the Attorney General had to petition Congress for a special appropriation of $\$ 300$. $^{8}$

The restricted personnel and finances of his Washington office were not the worst of the Attorney General's problems. If his Washington staff had to be overworked, at least they worked under his control. His subordinates in the field, including the district attorneys, were much more difficult to supervise. Troubles with them arose in part from the manner in which they were paid. Although the district attorneys earned a fixed salary of $\$ 200$ a year, most of their income came from fees paid by the Government according to the number of cases they conducted. These fees amounted on the average to about $\$ 4,000$ a year, and in some instances even exceeded the compensation of federal judges. ${ }^{9}$ As might be expected, some of the district attorneys responded more enthusiastically to piece-work pay than to the Attorney General's policies, and in 1890 the Attorney General urged, neither for the first nor last time, that the fee system be abolished. It led to "prosecutions with a view solely to make fees against persons who ought not to be prosecuted at all," and frequently encouraged fraudulent claims. ${ }^{10}$ It tended to dispose district attorneys to avoid difficult cases and to spend little effort searching out and investigating possible crimes. Quite apart from the fee system, the Attorney General could not feel confident that his instructions would be followed. He might admonish, cajole and scold the district attorneys; he could refuse to furnish temporary assistants

4. Id. at 10 .

5. Id. at 97.

6. Id. at 117 .

7. Id. at $128,148,168,169$.

8. Id. at $\mathrm{xv}$.

9. Id. at 37, 46-51. There were seventy-two district attorneys and the appropriation for their regular fees was $\$ 280,000$; there were in addition special appropriations and special compensations.

10. Id. at xxvii. See also Cunmings \& McFarland, Federal Justice $493-94$ (1937). The fee system was finally abolished in $\mathbf{1 8 9 6 .}$ 
and special funds; his six examiners occasionally inspected their accounts and records. But he did not appoint and could not easily dismiss these attorneys, whose positions were secured by the feeling that, as qualified professionals who had special knowledge of local conditions, they were most competent to resolve problems arising within their own districts.

Neither could the Attorney General, even if he wished to, offer much help in the preparation of their cases. His funds available to pay for assistant attorneys were never ample enough to satisfy the many requests, and he had virtually no resources for investigation. Only occasionally would United States marshals investigate local crimes, usually crimes of violence, which were still common and flagrant in the frontier territories. The six examiners of the Washington office were kept busy with routine work and were not, in any case, skilled detectives. Even had there been enough money with which to hire private investigators, the prejudice against Pinkerton agents was so well established that to use their services was out of the question. Investigation was, therefore, always difficult and often impossible. As late as 1903, when a father appealed for help in finding his kidnapped child, the acting Attorney General was forced to reply with the comforting words: "You should furnish me with the names of the parties holding your daughter in bondage, the particular place, and the names of the witnesses by whom the facts can be proved."11 Such difficulties would have impeded even the most determined enemy of trusts; they could have been overcome only by an Attorney General who determined to slight his other work and lead his grouped forces into an unknown field.

\section{Enforcement During President Harrison's Administration:} 1890-1892

\section{Department of Justice Policy}

William H. H. Miller, the Attorney General in 1890, moved slowly in administering the new act. Leaving enforcement mainly to the efforts of his district attorneys, he gently prompted them from time to time, encouraging them when it did not cost money, more closely supervising a few important cases. Consistent with this policy, the first case under the Sherman Act was instigated by a minor official and directed against obscure offenders. John Ruhm, the United States Attorney in Nashville, Tennessee, wrote to Miller a month after the act was passed that he would like to use it against a combination of mine owners and coal dealers who had raised the price of coal in Nashville several cents a bushel higher than it was in Memphis. He added that the ice dealers of Nashville were also "an unlawful combination" and offered to investigate them as well. ${ }^{12}$ Though the ice dealers passed out of the picture, the coal suppliers became the defendants in the first federal antitrust suit.13

11. Id. at 374 .

12. Letter from Ruhm to Miller, Aug. 7, 1890, Dep't Justice [hereinafter, D.J.] File 8247-J.1-1890.

13. United States v. Jellico Mountain Coal \& Coke Co., 43 Fed. 898 (1890), 46 Fed. 432 (C.C.M.D. Tenn. 1891). 
In answering Ruhm, Miller adopted his characteristic attitude. "If, in your judgment, after careful examination, a case can be made against any of the parties named, then, I take it, it is your duty to cause the necessary affidavit to be made, and have an examination before the commissioner, if that is deemed the proper course." After some further correspondence, Ruhm was authorized to file suit against the combination, ${ }^{14}$ but not before he sent the bill in equity to Washington for approval. ${ }^{15}$ It was handed to Solicitor General Taft, who suggested certain changes, especially the addition of a paragraph alleging "that the coal mines owned by the defendant corporations include all those from which it is practicable or profitable to send coal for consumption in the Nashville market . . . "10 Taft apparently hoped to strengthen the case by arguing that the Nashville Coal Exchange was not only a combination in restraint of trade but also a monopoly. Ruhm filed the bill with the circuit court, which in due course granted an injunction, observing "that the purposes and intentions of the association could hardly have been more successfully framed to fall within the provisions of the act ...."17

The Jellico Coal victory, unqualified and undisputed, since the defendants failed to appeal, was a hopeful beginning. By itself, however, it did not make a very impressive record for the administration, and the act was by now almost a year old. A few weeks later, G. A. Copeland, an editor of the Boston Daily Advertiser, wrote to Miller asking about his policy. Had he urged the district attorneys to act against the trusts? Had he tried to get evidence against "the well known Standard Oil Trust, the reorganized sugar trust of New Jersey, the cotton oil trust, or any of the better known combinations to restrict interstate trade?" If not, how did he propose to enforce a law that had been shown to be constitutional? These questions, Copeland said, were not intended as criticism; they arose from his "anxiety as a loyal Republican that the mark of the present administration shall be above honest and fair criticism."18 Miller, who of course recognized the implicit reproach, replied:

No special instructions have been issued to all the District Attorneys, with reference to the anti-trust law. We have, however, made a test case in Tennessee, and have obtained a decision in the United States Circuit Court in that state, sustaining the anti-trust law. Much doubt was expressed as to the validity of the law, and it was thought best, before taking any general action, to test this question. The District Attorneys of the Districts involving the operations of some of these larger trusts will soon be in-

14. Letter from Miller to Ruhm, Aug. 13, 1890, D.J. Instr. Bk. No. 4, at 224 ; Letter from Ruhm to Miller, Aug. 15, 1890, D.J. File 8247-c-1890; Letter from Taft to Ruhm, Aug. 25, 1890, D.J. Instr. Bk. No. 5, at 22; Letter from Ruhm to Miller, Aug. 30, 1890, D.J. File 8247-c-1890; Letter from Miller to Ruhm, Sept. 2, 1890, D.J. Instr. Bk. No. 5, at 124.

15. Letter from Ruhm to Miller, Sept. 5, 1890, D.J. File 8247-c-1890; Letter from Miller to Ruhm, Sept. 5, 1890, D.J. Instr. Bk. No. 5, at 186.

16. Letter from Taft to Ruhm, Sept. 12, 1890, D.J. Instr. Bk. No. 5, at 290.

17. United States v. Jellico Mountain Coal \& Coke Co., 46 Fed. 432, 436 (C.C.M.D. Tenn. 1891).

18. Letter from Copeland to Miller, June 24, 1891, D.J. File 8247-J.1-1890. 
structed to investigate and prosecute, if they can find any violations of the law. ${ }^{19}$

The instructions mentioned went out in July and August of $1891,{ }^{20}$ but beyond this the district attorneys were left to their own devices. When the district attorney in St. Louis asked for more detailed information, Miller wrote: "You can act upon your own judgment as to the best way of acquainting yourself with violations of the anti-trust law. Doubtless you will find the Tennessee case reported in Federal Reporter now or very soon."21 To another district attorney who asked about the meaning of the circular letter of instruction, Miller answered that "it was my intention to authorize and direct District Attorneys, in case there were indications of the existence of any trust or combination in violation of the law, to investigate thoroughly, and if any infraction of the law was found, to prosecute vigorously." The Department had not assigned any agent to make such investigations; "the case is like any other case of an alleged violation of Federal law, no special provision being made for compensation for its investigation or prosecution."22 And in general this was his policy. Once, when asked whether he would order the Sherman Act to be used against an alleged offender, he replied that he was not in the habit of directing district attorneys to bring particular cases, and had already gone further than was customary in issuing general instructions to enforce the act. ${ }^{23}$

\section{Results of Miller's Policy}

During the first eighteen months, therefore, attempts at enforcement depended on local conditions. Success encouraged the victor to seek fresh glory and inspired others to imitation. Ruhm, for one, was so elated by his first case that even before it was won, he eagerly offered to begin two or three more. ${ }^{24}$ Later he tried to enlist himself in the struggle against the whisky trust, ${ }^{25}$ and to engage in sole combat against the Southern Wholesale Grocers' Association. ${ }^{26}$ These additional ventures were not authorized by his chief, and his glowing promise was never fulfilled. On the strength of his single victory, however, newspapers celebrated him as "one of the keenest and most aggressive officers in the Department of Justice."27 Some colleagues rushed to follow his example, and for a few weeks it seemed as if the Sherman Act might become

19. Letter from Miller to Copeland, July 1, 1891, D.J. Misc. Letter Bk. No. 5, at 340.

20. E.g., Letters from Miller to Dist. Attorneys [hereinafter, D.A.'s] S.D.N.Y., N.J., E.D. Pa., July 2, 1891, D.J. Instr. Bk., No. 13, at 414; Circular from Att'y Gen. to D.A.'s, July 20, 1891, Circular F-8247-1890.

21. Letter from Miller to Reynolds, July 15, 1891, D.J. Instr. Bk. No. 14, at 61.

22. Letter from Miller to Remick, D.A., N.H., July 31, 1891, D.J. Instr. Bk. No. 14, at 314 .

23. Chicago Tribune, Aug. 5, 1891, p. 9, col. 1.

24. Letter from Ruhm to Miller, Sept. 22, 1890, D.J. File 8247-1890.

25. Letter from Ruhm to Miller, March 29, 1892, D.J. File 8247-J-1890.

26. Letters from Ruhm to Miller, April 13, May 20, July 18, 1892, in ThoReIti, The Federal Antitrust Policy 375 n.34 (1954).

27. Chicago Tribune, Aug. 5, 1891, p. 9, col. 1. 
a weapon specially adapted to chastising coal merchants. On August 3, 1891, the district attorney in Chicago announced that he was beginning to look into the combination of coal dealers there. ${ }^{28}$ On August 4th, it was reported that federal officials in New York State had investigated the Lockport Coal Exchange and the Buffalo coal syndicate. ${ }^{29}$ On the same day, the Attorney General was urged to invoke the act against a Tennessee coal mine that was said to have combined with several railroads. ${ }^{30}$ In all of these instances, however, the first spurt of energy was the last. A few other district attorneys, on their own initiative, tried their hands against assorted offenders. James Remick, in New Hampshire, unsuccessfully urged a grand jury to indict the bobbin trust, ${ }^{31}$ and John Reed made an abortive attempt against the oleomargarine trust. ${ }^{32}$

Meanwhile, the Attorney General passed along information and complaints. He recommended that district attorneys pay "careful attention" to "Drug Trusts." 33 He forwarded to the district attorney in Iowa a letter complaining about the formation of a "wheat trust," a scheme supposedly sponsored by the Farmer's Alliance whereby farmers would raise the prices of grain by withholding their crops from the market. ${ }^{34}$ Having read in the newspapers that a window-glass combine had been formed in Pittsburgh, he asked the attorney there whether he was taking action. The attorney answered that he would promptly investigate if only he were told which newspaper contained the report, to which Miller responded: "I beg to say that I do not now remember in what paper I saw the reference to the alleged violation. . . . However, you will be able, I suppose, to find out the state of matters by inquiry in your city." 35 Judicious and necessary as this reliance on the initiative of district attorneys may have been, it had nevertheless produced only one prosecution. Hostile newspapers were not long in alleging that "department agents" were "trying to make the statute an object of contempt."36

This criticism was all the more damaging because none of the major trusts had yet been so much as threatened. Not that Miller had entirely overlooked them. During the summer of 1891, he had ordered the district attorney in Ohio

28. Chicago Tribune, Aug. 3, 1891, p. 1, col. 5.

29. N.Y. Times, Aug. 4, 1891, p. 1, col. 1 .

30. Chicago Tribune, Aug. 5,1891, p. 9, col. 1 .

31. N.Y. Times, Dec. 16, 1891, p. 1, col. 4; id., March 10, 1892, p. 4, col. 3; Letter from Remick to Miller, Dec. 21, 1891, in Thorelli, The Federal Antitrust Policy 376 n.35 (1954).

32. Letter from Reed to Miller, Jan. 11, 1892, in Thorelli, The Federal Antrtrust Policy 376 n.35 (1954); Chicago Tribune, Jan. 9, 1892, p. 4, col.. 3.

33. Circular from A.G. to D.A.'s, Aug. 13, 1891, D.J. File 8247-1890; Letter from Miller to Marshall, D.A., N.D. Tex., Aug. 13, 1891, D.J. Instr. Bk. No. 14, at 514.

34. Letter from Miller to O'Connell, D.A., Iowa, Aug. 14, 1891, D.J. Instr. Bk. No. 14, at 527. Rumors of the plan to form a "trust" were current in the newspapers. See Chicago Daily News, July 29, 1891, p. 2, col. 7.

35. Letter from Miller to Lyon, Sept. 24, 1891, D.J. Instr. Bk. No. 15, at 339; Letter from Lyon to Miller, Sept. 25, 1891, D.J. File 8247-1890; Letter from Miller to Lyon, Oct. 1, 1891, D.J. Instr. Bk. No. 16, at 93.

36. N.Y. Times, March 10, 1892, p. 4, col. 3. 
to investigate the Standard Oil Company, referring to "a popular belief that its operations are in gross violation of the purposes of the [antitrust] law";37 but nothing further came of it. Moreover, Miller apparently desired that action be brought against the whisky trust, which reached a peak of unpopularity after George Gibson, one of its officers, was indicted for plotting to dynamite a competitor's factory. ${ }^{38}$ Here, Miller was frustrated for half a year by Milchrist, the district attorney in Chicago, within whose jurisdiction the whisky trust had its headquarters. Although Milchrist kept promising to investigate, he ultimately reported his belief that the trust was immune from the Sherman Act. ${ }^{39}$ One day he announced to the newspapers that though the trusts had held "almost absolute sway," "the hour of retribution is at hand." 40 A few days later he told interviewers:

Now a great many people believe I ought to begin proceedings at once against the so-called whisky trust, but an examination I have made has cleared away an impression I had that the Cattle Feeding and Distilling company is a combination we can reach under the anti-trust law. The company cannot be reached under the Federal statutes as it owns all its

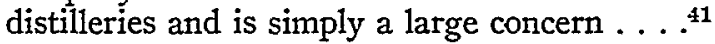

That this was a plausible view of the matter was demonstrated later, when the courts held that the whisky trust, being a single corporation, could not by its mere existence violate section one of the Sherman Act. ${ }^{42}$ At this time, however, Miller apparently did not share Milchrist's conviction. He may have believed, as many did, that a corporation formed by merging the members of a combination would be construed as a combination under the Sherman Act; or he may have thought, as the Government's eventual pleadings against the whisky trust suggest, that a successful attack could be launched, if not against its mere existence, then against its activities. Yet Milchrist would not be persuaded to act. In August, he again promised Miller to investigate, ${ }^{49}$ and in January of 1892 , he signified that he had enough evidence to go before a grand jury. But this report was premature, and for all his earnest investigating, he did not bring the hour of retribution closer. ${ }^{44}$

37. Letter from Miller to Brinsmade, Aug. 14, 1891, D.J. Instr. Bk. No. 14, at 517.

38. Gibson was arrested on Feb. 11, 1891, and the story was prominent in the newspapers during the following week. See N.Y. Times, Feb. 12, 1891, p. 1, col. 3 ; id., Feb. 13 , 1891, p. 8, col. 3. See also 2 Gresham, Life of W. Q. Gresham 640-47 (1919). Milchrist was responsible for the prosecution, which was unsuccessful, and a final nolle prosequi was entered on June 24,1892, just as the Sherman Act indictment was being quashed. N.Y. Times, June 25,1892 , p. 5 , col. 6 .

39. Letter from Milchrist to Miller, June 24, 1891, D.J. File 8247-J-1890.

40. Chicago Daily Tribune, Aug. 3, 1891, p. 1, col. 5.

41. Chicago Inter Ocean, Aug. 5, 1891, p. 7, col. 2.

42. In re Greene, 52 Fed. 104 (C.C.S.D. Ohio 1892).

43. Letter from Miller to Milchrist, Aug. 14, 1891, D.J. Instr. Bk. No. 14, at 518; Letter from Milchrist to Miller, Aug. 21, 1891, D.J. File 8247-J-1890.

44. Chicago Tribune, Jan. 8, 1892, p. 5, col. 7. But in his letter to Olney on Oct. 2, 1893, D.J. File $8247-1890$, Milchrist said that there had never been enough evidence to support an indictment. 
With the beginning of 1892 , however, Miller's own efforts began to produce some action. District Attorney Frank Allen in Boston, to whom Miller, despairing of Milchrist's willingness, had assigned the duty of destroying the whisky trust, reported that he was ready to proceed. His preparation had been facilitated by unusual assistance: he had been allowed to borrow one of the Department's investigators ${ }^{45}$ and, with this aid, had gathered enough evidence to request an indictment, which a grand jury issued in February. ${ }^{46}$ But hope quickly faded. By May, Judge Nelson of the district court in Boston had quashed the indictment, maintaining that it was "clearly insufficient according to the elementary rules of criminal pleading," because, although it alleged that the trust had been engaged in monopolistic activities, it neglected to mention their interstate character, a necessary averment under the statute. ${ }^{\mathbf{4 7}}$

Miller, who had seen Judge Nelson's decision reported in the newspapers, sought an explanation. The defect, Allen wrote, was the fault of a typist who omitted the vital line. "The amount of work which we have had to do in this office, with the really insufficient clerical force renders us at times liable to some slip of this kind, which I am very glad to say, was only a slip and not the result of carelessness in the preparation of the indictment." 48 He could, however, begin again, for, having recognized the weakness in the original accusation as soon as the defense moved to quash, ${ }^{49}$ he had prepared an improved and more detailed indictment, which the grand jury returned several days before Nelson's opinion was published. ${ }^{50}$ On the strength of this new indictment, the officers of the trust were arrested again. This time they refused to give bond for appearance in Boston, preferring to contest the indictment in courts in their various districts. ${ }^{51}$ The case against the trust thus became three preliminary proceedings in different parts of the country, and now, for the first time, long letters traveled between Washington and the outposts, the Attorney General giving minute advice, the district attorneys carefully revising their plans. ${ }^{\text {be }}$ All the hard work did not help. Although the new indictment

45. 1892 ATT'y GEN. ANN. REP. at xix, 84-85; Letter from Allen to Miller, Jan. 11, 1892 , D.J. File $8247-1890$. Somewhat later, the investigator, D. M. Horton, was seeking evidence against the cordage trust in Chicago. See Boston Herald, March 6, 1892, p. 3, col. 2.

46. N.Y. Times, March 1, 1892, p. 2, col. 3.

47. United States v. Greenhut, 50 Fed. 469,471 (D.C. Mass. 1892).

48. Letter from Allen to Miller, May 14, 1892, D.J. File 8247-1890. It is difficult to see from the text of the indictment, as quoted in the N.Y. Times, March 3, 1892, p. 6, col. 2 , how any omission occurring, as Allen put it, "in the last line," could possibly have created the difficulty.

49. N.Y. Times, March 20, 1892, p. 3, col. 2.

50. Letter from Allen to Miller, May 24, 1892, D.J. File 8247-1890. The indictment was returned on May 10 and filed in the circuit court on May 14.

51. N.Y. Times, June 10, 1892, p. 6, col. 6; id., June 12, 1892, p. 9, col. 5; Letter from Herron, D.A., S.D. Ohio, to Miller, May 24, 1892, D.J. File 8247-1890.

52. D.J. File \$247-1890, and, e.g., Letter from Miller to Brinsmade, D.A., N.D. Ohio, June 6, 1892; Letter from Miller to Herron, May 27, 1892, June 6, 1892; D.J. Instr. Bk. No. 22, at 318, 206. 
corrected the faults of the original, the judges were evidently captivated by Nelson's opinion, and each of them found more subtle defects rendering it insufficient. ${ }^{53}$ The case having collapsed completely by June, Miller and Allen agreed that attempts at resuscitation were pointless. ${ }^{54}$

Miller's second great effort fared little better. Since the beginning of 1892 , rumors had been circulating that the sugar trust was about to buy out its last substantial competitors, four refineries in Philadelphia that reputedly produced one third of the country's output. ${ }^{.5}$ For some time the story was denied by the principals. John Searles, treasurer of the trust, told the stockholders that "so far as the American Sugar-Refining Company is concerned, we have nothing to do with the store on the other corner." Claus Spreckels, one of the independents, said that he would never sell. Even after the contract had been signed, E. C. Knight would only concede that it was "not improbable an understanding [might] . . . be reached" between the trust and him. ${ }^{66}$ But, by the end of March, it was known that the merger had been arranged-a transaction by which the most notorious trust would perfect its control and become, for the time being at least, virtually absolute. No circumstance could more clearly test the willingness of the Government to use the Sherman Act and the power of the act to control the big trusts. It was not long, therefore, before Owen Scott, a Democrat from Illinois, introduced a resolution in the House of Representatives asking the Attorney General what he proposed to do. ${ }^{57}$ Miller's answer was ready; he had anticipated prompting of this sort, and had already begun a suit to invalidate the sale. ${ }^{58}$ Yet he had no reply for critics who wondered why a civil suit should be brought against these offenders when the officers of the whisky trust had been indicted as criminals. ${ }^{50}$ The sugar trust proceedings moved so slowly, however, that it was almost two years before the case reached the courts, and by then Miller had left office. ${ }^{60}$

53. In re Corning, 51 Fed. 205 (N.D. Ohio 1892); In re Terrell, 51 Fed. 213 (C.C. S.D.N.Y. 1892); In re Greene, 52 Fed. 104 (C.C.S.D. Ohio 1892).

54. Letter from Wyman, Acting D.A., Mass., to Miller, Sept. 6, 1892, D.J. File 82471890.

55. The Government asserted that at this time $65 \%$ of the nation's refined sugar was produced by the trust, $33 \%$ by the four Philadelphia firms-Knight, Spreckels, Franklin, and Delaware-and the remaining $2 \%$ by the Revere Refinery of Boston. Record, United States v. E. C. Knight Co., 156 U.S. 1 (1895), filed March 29, 1894.

56. N.Y. Times, Jan. 14, 1892, p. 3, col. 4; $i d$., March 20, 1892, p. 8, col. 2. The contract between the trust and Knight was dated March 4, 1892. Record, p. 83, United States v. E. C. Knight Co., 156 U.S. 1 (1895).

57. 23 CoNG. REC. 3366, 3926-29 (1892). The resolution was introduced on April 16, 1892, and adopted on May 4, 1892.

58. H.R. Exec. Doc. No. 225, 52d Cong., 1 Sess. (1892). Miller reported that suit had been filed on May 2, 1892. Apparently, the resolution came after the action began, for Miller instructed Ingham on April 11 to institute proceedings; and on April 14 the acting Attorney General wrote Ingham asking what aid he would like. Record, p. 2, United States v. E. C. Knight Co., 156 U.S. 1 (1895) ; D.J. Instr. Bk. No. 21, at 77.

59. E.g., Editorial, N.Y. Times, June 8, 1892, p. 4, col. 4.

60 . The defendant's answers were filed between July 1892 and January 1893; the ex- 
There were other defeats on the record. In a criminal action brought against the Mississippi River Valley Lumbermen's Association for concerted action to raise lumber prices, the indictment was found insufficient. ${ }^{61}$ And a suit to dissolve the Trans-Missouri Freight Association, one of the most important railroad pools in the west, begun in January of 1892 , was lost by autumn. ${ }^{62}$ Joseph Ady, district attorney in Topeka, who was so devoted to this cause that he paid for an assistant counsel from his own pocket, ${ }^{63}$ urged Miller to authorize an appeal, arguing that, if the opinion stood unchallenged, it would provide a complete defense for almost all "of those great aggregations of capital which the public has been used to look upon as a menace to our institutions, and therefore a proper subject of prohibitory legislation." ${ }^{44}$ Miller consented;65 but the appeal was decided against the Government a year later. ${ }^{66}$

Few compensating victories stood out against this string of defeats. In its first effort to apply the Sherman Act to a labor dispute, the Government succeeded in having a general strike in New Orleans enjoined, though the injunction was not granted until months after the strike ended.67 An indictment against the cash-register trust was upheld, at least in part. ${ }^{68}$ Although the decision may have soothed District Attorney Allen, who, following his abortive whisky-trust prosecution, had been suffering from a rash of insufficient indict-

aminer held hearings in October 1892 and January and February 1893; and he filed his report in October 1893. The case was not argued in court until January 19, 1894. Record, pp. 1475, 208, United States v. E. C. Knight Co., 156 U.S. 1 (1895).

61. United States v. Nelson, 52 Fed. 646 (D. Minn. 1892). The indictment was returned on Jan. 20, 1892, CCH Federal Antitrust Laws 68 (1952); the warrants issued on Feb. 10, 1892, N.Y. Times, Feb. 11, 1892, p. 9, col. 3 ; id., Feb. 13, 1892, p. 1, col. 6, and the opinion was filed on Oct. 10, 1892 .

62. Although the opinion was not delivered until Nov. 28, 1892, United States v. TransMissouri Freight Ass'n, 53 Fed. 440 (C.C.D. Kan. 1892), it was generally believed soon after the argument was concluded in August that the decision would favor the defendants. N.Y. Times, Aug. 4, 1892, p. 2, col. 5.

63. Letter from Ady to Miller, Dec. 2, 1892, in Thorelli, The Federal Antitrust PoLIcy 377-78 (1954). Ady hoped that Miller would ask Congress for a special appropriation to reimburse him.

64. Letter from Ady to Miller, Dec. 1, 1892, D.J. File 8247-1890.

65. Letter from Miller to Ady, Dec. 6, 1892, D.J. Instr. Bk. No. 26, at 351.

66. United States v. Trans-Missouri Freight Ass'n, 58 Fed. 58 (8th Cir. 1893), rev'd, 166 U.S. 290 (1897).

67. United States v. Workingmen's Amalgamated Council, 54 Fed. 994 (C.C.E.D. La.), aff'd, 57 Fed. 85 (5th Cir. 1893). The bill for injunction was authorized on Nov. 8, 1892, and filed on Nov. 10, when the strike was at its height. Letter from Miller to Earhart, D.A. La., Nov. 8, 1892, D.J. Instr. Bk. No. 25, at 457, in Cummings \& McF ARLAND, FEDERAL Justice 437-38 (1937).

68. United States v. Patterson, 55 Fed. 605 (C.C.D. Mass. 1893) (demurrer to indictment sustained as to fourteen counts, overruled as to four). Subsequently, a petition for rehearing was granted. 59 Fed. 280 (C.C.D. Mass. 1893). For details of the indictment, see N.Y. Times, July 10, 1892, p. 17, col. 2. 
ments, ${ }^{69}$ the case was eventually dropped..$^{70}$ The cash-register proceeding is nevertheless of special interest because it was one of the several cases in which the Government cooperated with private persons injured by trusts. In this instance, the indictment was drawn by the attorney for the Lamson Store Service Company, one of the firms alleging that its business was being destroyed .by the trust's coercive acts. ${ }^{71}$ On another occasion, when the Mather Electric Company complained that coercive practices of the General Electric Company jeopardized its business, Allen supported the private suit by filing a similar one on behalf of the Government. ${ }^{2}$

When all was said and done, the Government during President Harrison's administration had brought seven antitrust cases to court and won only two. This record caused some anxiety among Republican leaders during the presidential campaign of 1892, and some of them sought to attribute the poor showing to a weakness in the act itself. ${ }^{73}$ But the party platform generally reaffirmed its faith in the statute and endorsed the record of its administration. ${ }^{74}$

\section{The Program of Richard Olney, Attorney General Under President Cleveland}

\section{Olney's Attitude Toward the Sherman Act}

The election of 1892 was fought mainly on the tariff issue. The Democrats emphasized as before their conviction that the tariff was the mother of trusts, ${ }^{75}$ though they were willing to agree with their opponents that prohibitive antitrust legislation could be of some value in controlling the combines. Their plat-

69. Not only were Allen's indictments against the whisky trust held to be insufficient, see text accompanying notes 47-53 supra, but in United States v. Potter, 56 Fed. 83 (C.C. D. Mass. 1892), a case involving the banking laws, the court sustained demurrers to two of the three indictments for the same reason. The New York Times did not hesitate to suggest that the defects were deliberate. N.Y. Times, June 13, 1892, p. 4, col. 2; id., June 16,1892 , p. 4 , col. 5 ; id., June 20,1892 , p. 4 , col. 3 .

70. The Government entered a nolle prosequi on Nov. 10, 1894. 1890-1918 DECREES \& Judgaents in Federal Antu-Trust Cases 680.

71. See Letter from Hoar, Allen's successor as D.A., Mass., to Att'y Gen., Oct. 11, 1893, in Thorelir, The Federal Antitrust Policy 378 (1954). Thorelli describes the participation of the Lamson Company as "rather sensational," apparently unaware that the practice was neither novel, irregular, or in this instance, unknown to Miller. See Letter from Miller to Allen, June 3, 1892, D.J. Instr. Bk. No. 22, at 2831/2.

72. On July 16,1892, two bills in equity were presented to Judge Colt of the circuit court in Boston; in one, the Mather Electric Company was the complainant; in the other, the Government. Both bills alleged that the Mather Company stood in danger of losing a contract because the General Electric Company, a combination, fraudulently represented that the Mather Company was infringing its patents and unable to fulfill the contract. Colt refused to grant a temporary injunction, and set a hearing for July 25 . N.Y. Times, July 17,1892 , p. 16 , col. 5 . There seems to be no further record of the case.

73. See N.Y. Times, June 8, 1892, p. 4, col. 4 (quoting statement at the Republican national convention by ex-Gov. Brackett of Massachusetts).

74. McKee, Nattonal Conventions and Platrorms 272 (4th ed. 1901).

75. Id. at 264 . 
form asserted: "[W]e believe [the trusts'] . . . worst evils can be abated by law, and we demand the rigid enforcement of the laws made to prevent and control them, together with such further legislation in restraint of their abuses as experience may show to be necessary."76 This demand for "rigid enforcement," however sincere, was partly conventional, since no campaign manager could present to the public a proposal for lax enforcement; more important, it was an obvious attack on the record of the previous administration. The Democratic announcement nevertheless failed to recognize that by now any enforcement policy would face the difficult problem of persuading the judiciary that the act was not toothless. Cleveland recognized this difficulty, and in his inaugural address made a more guarded promise to assault the trusts: "To the extent that they can be reached and restrained by the Federal power the General Government should relieve our citizens from their interference and exactions." "77

Richard Olney, Cleveland's Attorney General, did not believe that the Sherman Act could reach or restrain monopolies to any great extent. Since Olney did not hide his scepticism, he has often been held culpable for the act's weakness - on the theory that a man who questions the sharpness of his knife really does not want to cut anything. But this argument is inapplicable to an Attorney General, who, like a surgeon, should refuse to work with instruments that may injure rather than cure. The precise question is whether Olney refrained from employing the act because he believed it to be ineffective, or only because he was hostile to its purposes.

The evidence that is supposed to impugn his sincerity is sparse. Much has been made of the fact that among Olney's clients were a number of large corporations, as though a lawyer must always be prejudiced in favor of his clients. Still more sinister conclusions have been drawn from a letter Olney wrote, soon after being offered the cabinet office, to the president of the Chicago, Burlington \& Quincy Railroad, which he served as counsel: "Among other things that I want to find out is where I am going to stand with my present clients.... I am not a millionaire and cannot take any office of the sort without a good deal of pecuniary sacrifice-just how much I should like to ascertain." The railroad's president answered, "It shall make no difference in our relations except such as you may think it expedient to make." Olney's law partners also approved of his accepting the post. ${ }^{78}$ It was perhaps timorous of Olney to worry about the consequences of injuries he might cause his clients while Attorney General - the office is supposed to demand fearless performance of duty. The letter nevertheless testifies to his good faith, since it would have been

76. Ibid.

77. Inaugural Address of Grover Cleveland, March 4, 1893, in 9 Richardson, MEsSages \& Papers of the Presidents 391 (1900).

78. See Letter from Olney to Perkins, Feb. 16, 1893, in Olney Papers (Lib. Cong.); Letters from Perkins to Olney, Feb. 17, 1893, Feb. 18, 1893, in Olney Papers; Letter from Forbes to Perkins, Feb. 20, 1893, in Olney Papers and Cummingas \& McFardand, Federad. JUSTICE 321 (1937). 
superfluous had he already decided to suit his future actions to the desires of his clients.

Possibly, however, Olney believed that the Sherman Act was harmful and ought to be repealed. Such a belief is suggested by a letter that he wrote to Secretary of the Treasury Carlisle in 1893 informing him that certain people Olney knew wished to organize an attempt to repeal the act, and asking for a list of senators "who ought to be persuaded to see the thing in the right light."7g Certainly, by about 1905, when he wrote a series of articles on the subject, he had come to believe that the policy of the act was misconceived. ${ }^{80}$ His arguments were familiar ones at the time, much like those advanced by the great trust-buster, Theodore Roosevelt. Olney maintained that while very large firms were beneficial because they could produce so efficiently, ${ }^{81}$ they were also dangerous. By concentrating wealth in a few hands, the trusts tended to separate the country into distinct classes of rich and poor, and those who controlled these great accumulations of wealth were powerful enough to represent a menace to free institutions. ${ }^{82}$ But it was ridiculous, Olney believed, to try to overcome these defects by outlawing trusts: if they could be successfully prohibited, the community would be deprived of their positive advantages; besides, as a matter of fact, they could not be abolished. In an article published in 1906, Olney argued that their benefits were proved by their persistence:

... the "trust" has earned the right to be regarded as an economic evolution. That it is such there could be no stronger proof than that the "trust" not only continues to exist but to actually grow and flourish. It has encountered such a degree of popular prejudice, has been so bitterly condemned by the press and from the platform, has been such a favorite theme for denunciation by political demagogues, and has been so unrelentingly harried by legislatures and by courts, that its unimpaired and even increased vitality must be deemed to be another signal instance of the ineffectiveness of artificial restraints when opposed to the operation of natural laws. ${ }^{83}$

The problem was how to ensure that the community would enjoy the benefits of trusts without suffering from their "sinister and injurious operation." "s4 Olney's answer, an early hint at the "countervailing power" theory, was that

79. Letter from Olney to Carlisle, July 5, 1893, in Olney Papers (Lib. Cong.) and Cummings \& McFartand, Federal Justice 322 (1937).

80. His views may, of course, have changed in the meantime, perhaps even as a result of his experience as Attorney General. A hint that the later articles represented an earlier view, however, is contained in 1893 ATT'Y GEN. ANw. REP. at xxvi-xxwii, where Olney wrote, "all ownership of property is of itself a monopoly ...." This remark, so reminiscent of William Graham Sumner, has its counterparts in the later articles, in such phrases as "economic evolution," "artificial restraints and natural law."

81. Olney, Labor Unions and Politics, The Inter-Nation, Dec. 1906, pp. 23-24; Olney, Modern Industrialism, The Inter-Nation, Feb. 1907, pp. 29, 32.

82. Olney, Modern Industrialism, supra note 81, at 32.

83. Olney, Labor Unions and Politics, supra note 81 , at 24.

84. Id. at 25-29. 
the trusts would be sufficiently restrained by labor unions and potential competitors; the government need only deny tariff protection to those who abused it, prevent discrimination by public utilities and railroads, and perhaps eliminate patent monopolies. ${ }^{85}$

The theory of the Sherman Act, Olney had concluded by 1907, was altogether mistaken. In the first place, it sought to prohibit the progressive tendency of capital and of labor to form themselves into large units of operation. If a statute was necessary at all, it ought to be an intelligent and impartial one which would be "in the interests of both classes-, of both labor and capital; [and would] concede the right to combine and organize to each class . ..."86 Second, the Sherman Act failed to provide for what might be useful-regulation, rather than a futile and misdirected effort at prohibition. On this point, Olney said:

The hoary axiom- "Competition is the life of Trade"-in the sense in which it has been heretofore understood and acted upon is, I believe, thoroughly discredited. The competition of the future promises to be a regulated competition-a competition regulated by law, so regulated as to be fair. ... [I]f business enterprises and the mutual relations of business men ought to be regulated in the interest of fair play, justice, and equality of opportunity and treatment-such assuredly meritorious objects are not to be refused recognition because not within the conception of men of past generations. ${ }^{87}$

In short, Olney believed at this time that the Sherman Act was based on a false economic theory and was therefore incapable of achieving even its misguided goals.

Still, there is no reason to think that this view, assuming Olney already held it in 1893, affected his administration of the act. He could, and did, amply justify his policy by the antitrust decisions which the courts had thus far handed down. In a review of these cases, published in his first annual report, he showed that the act as it had been interpreted could not really affect many of the supposed offenders. As a matter of constitutional principle, it could govern only businesses engaged in interstate commerce. Nor did it actually affect every one of these, since the courts had held in the Trans-Missouri case that the Sherman Act was inapplicable to railroads, and, in one of the whisky trust prosecutions, that it did not reach monopolies unless they were exclusive. "[T] he cases popularly supposed to be covered by the statute," he wrote, "are almost without exception obviously not within its provisions, since to make them applicable not merely must capital be brought together and applied in large masses, but the accumulation must be made by means which impose a legal disability upon others from engaging in the same trade or industry." Since this was for the moment the unvarying opinion of the courts, the Attor-

S5. Olney, Modern Industrialism, supra note 81 , at 39-42.

86. Id. at 42 .

87. Address by Richard Olney before the Merchants Club of Boston, 1913, in JAMrs, Richard Olney and his Public Service 190-91 (1923). 
ney General quite properly announced that he would not prosecute where statutory authority seemed so feeble. ${ }^{88}$

\section{The Sugar Trust Test}

Although he had stated a position on which he could quite easily have rested, Olney saw fit to test his conclusions. Despite his estimate of how the courts would interpret the act and regardless of any views he might have had about the wisdom of Congress's antitrust policy, he decided to obtain a more authoritative judgment by bringing a test case before the Supreme Court as soon as possible. ${ }^{89}$ For this test, he chose the suit against the sugar trust. It was ideal for his purpose. It could be brought to trial quickly, since the preliminary preparations were finished. Briefs and answers had been filed, the examiner had completed his hearings, and Ellery Ingham, the district attorney at Philadelphia, who had been in charge of the proceedings since they began, was ready to proceed..$^{90}$ Moreover, the sugar trust was extremely unpopular and as clearly monopolistic as any. Until such an offender had been tried, a doubt would always remain about the act's meaning.

The subsequent history of the Sugar case bore out Olney's judgment of the law's ineffectiveness. During 1894 the Government was defeated in the circuit court and then in the court of appeals. ${ }^{91}$ And, early the following year, the Supreme Court upheld the lower court decisions. The court ruled that even if the trust monopolized the manufacture of sugar, it had not been shown to have a monopoly of interstate commerce and therefore was not subject to the federal statute. ${ }^{92}$ This outcome was exactly what Olney's analysis of previous decisions had suggested to him. As he wrote to his secretary after the final decision was published: "You will have observed that the government has been defeated in the Supreme Court on the trust question. I always supposed it would be and have taken the responsibility of not prosecuting under a law I believed to be no good." 93 That he was justified in not enforcing the act if he

88. 1893 Atr'y Gen. ANn. Rep. at xxvii. The decisions to which Olney referred as limiting the scope of the act were: United States v. Trans-Missouri Freight Ass'n, 53 Fed. 440 (C.C.D. Kan. 1892), aff'd, 58 Fed. 58 (8th Cir. 1893), rev'd, 166 U.S. 290 (1897); In re Greene, 52 Fed. 104 (C.C.S.D. Ohio 1892) (opinion by Jackson, J.).

89. 1893 ATt'x GEN. ANN. REP. at xxvii.

90. Olney entered office on March 6, 1893. The bill of complaint in United States v. E. C. Knight Co., 156 U.S. 1 (1895), had been filed May 2, 1892; answers had been entered Jan. 17, 1893; and the examiner had completed his hearings on Feb. \&, 1893. The examiner was apparently responsible for much of the delay from that time forward, for his report was not filed until Oct. 27, 1893. See Record, pp. 1, 72, 75, United States v. E. C. Knight Co., supra.

91. United States v. E. C. Knight Co., 60 Fed. 306 (C.C.E.D. Pa.), aff'd, 60 Fed. 934 (3d Cir. 1894).

92. United States v. E. C. Knight Co., 156 U.S. 1. (1895).

93. Letter from Olney to Straw, Jan. 22, 1895 in Olney Papers (Lib. Cong.) and Cummings \& McFarland, Federal Justrce 323 (1937). He made a similar statement to the press. See N.Y. Times, Jan. 22,1895, p. 16, col. 2. 
believed it was ineffective, seems beyond doubt, and the defeat in the sugar trust test seemed to vindicate his policy. ${ }^{94}$

\section{The Pullman Strike}

After the sugar trust suit, Olney allowed the Sherman Act to be used only once-during the Pullman strike of 1894. The dispute began in May, when

94. The seriousness of the defeat, and the Supreme Court's insistence that the case presented before it did not involve interstate commerce, has led many critics to maintain that the Government was not well prepared. Senator Edmunds held that the bill of complaint did not sufficiently stress the sugar trust's activities in interstate commerce, Letter from Edmunds to Sleicher, Jan. 2, 1903, in 36 Cong. Rec. 1901 (1903), and William Howard Taft later agreed, Taft, The Anti-Trust Act and the Suprenre Court 59 (1914). Even if this be true-and by no means is it certain that greater emphasis on the jurisdictional point in the bill of complaint would have impelled the Supreme Court to decide for the Government-it is no reflection on Olney, for the bill was filed on May 2, 1892, almost a year before Olney became Attorney General. See note 90 supra. Nevertheless, later attempts to explain the defeat assumed an increasingly personal flavor, as in Nevins' remark that "Olney allowed the suit against the Sugar Trust to go to trial in deplorably weak form ...." Nevins, Grover Cleveland 722 (1932). But there is no evidence to show that the case was carelessly prepared, or that Olney, as Nevins implies, allowed it to proceed knowing that it had remediable flaws.

Still less warranted is the conclusion drawn by Mrs. Gresham and endorsed by Thorelli that District Attorney Ingham deliberately sabotaged the Government's case, omitting evidence on interstate commerce because he had been bribed by the trust. 2 GRESHAMr, LIFE of W. Q. Gresham 653 (1919) ; Thorelli, The Federal Antitrust Policy 387 (1954). No doubt the sugar trust was capable of such maneuvering; in fact, at the very time the case was before the Supreme Court, a congressional committee was investigating charges that the trust had bribed senators to pass more favorable tariff rates. Moreover, according to an unsupported statement by Mrs. Gresham, Ingham was later convicted for complicity in counterfeiting. 2 GreshaMr, op. cit. supra at 653 . These two indications of criminality, however, form the basis of a conclusion which, apart from its logical defects, is falsified by other facts. First, Ingham never had a free hand in preparing the case. The original bill seems to have been drawn up by Solicitor General Charles H. Aldrich. Troonecli, $o p$. cit. supra at 386. A special counsel, former Solicitor General Samuel F. Phillips, appeared at Ingham's side during most of the proceedings. (He was appointed Sept. 13, 1892, by Miller, 1892 AtT'y Gen. ANN. Rep. at xx, 249, and was present at the pretrial hearings between October 1892 and February 1893, as well as before the court of appeals, Record, p. 75, United States v. E. C. Knight Co., 156 U.S. 1 (1895).) And when the case came before the Supreme Court, Ingham took no part at all.

Second, and even more significant, the judges who heard the case were not unanimous in holding the evidence of interstate commerce insufficient. Justice Harlan thought it was ample. See United States v. E. C. Knight Co., supra at 43-44 (dissent). And the trial court was convinced by the evidence that the trust sold sugar throughout the country and that its object in buying the refineries was "to obtain a greater influence or more perfect control over the business of refining and selling sugar in this conntry." United States v. E. C. Knight Co., 60 Fed. 306, 308 (C.C.E.D. Pa. 1894). (Emphasis added.) This fact, often forgotten, tends to vitiate allegations that the Government failed altogether to introduce evidence on commerce. The opinions suggest that the fatal flaw was elsewhere: since the complaint was directed against the acquisition of refineries, the case was about refining and not about the trust's commercial activities as such; on this view, no amount of evidence on commerce would have been enough to change a decision directed to the essence of the complaint. 
workers at the Pullman factory struck against a cut in wages. The American Railway Union, led by Eugene Debs, decided to support their fellows by refusing to handle after June 26th any train carrying Pullman cars; the boycott quickly became a general railroad strike throughout the central and western states. The federal government was drawn in when the acting Postmaster General notified Olney that strikers were obstructing the passage of United States mails. Olney immediately instructed United States attorneys to apply to federal courts for orders restraining this interference, and several courts issued injunctions against the strikers. During the first week of July, the situation deteriorated. Mobs gathered at railroad yards, blocked the rails, overturned cars, and jammed switches; they refused to disperse and, in some instances, went on to burn cars, bridges and depots, to derail locomotives and to attack police and deputy marshals. Vigorous action of some sort had to be taken and, after the strikers had refused to obey federal court injunctions, the Government decided to command obedience by sending in federal troops. ${ }^{95}$

That Olney should have authorized action under the Sherman Act in such circumstances may seem especially incongruous, for he had written only a few months earlier:

It should, perhaps, be added, in this connection-as strikingly illustrating the perversion of a law from the real purpose of its authors - that in one case the combination of laborers known as a "strike" was held to be within the prohibition of the statute, and that in another, rule 12 of the Brotherhood of Locomotive Engineers was declared to be in violation thereof. ${ }^{90}$

Moreover, when, in May 1893, he had been asked to authorize proceedings against the Tonawanda Lumber Shovers' Union-which had been accused of interfering with the business of certain importers-he had refused. Maintaining that the Sherman Act was not intended as a sanction against labor organizations, he had said that to employ the act in this particular instance would unfairly place "the whole power of the federal government on one side of a civil controversy, of doubtful merits, between the employers of labor on one hand and the employed on the other."97 But, in fact, the plan of introducing the Sherman Act into the Pullman strike was not of his making.

Olney's first reaction to the Postmaster General's complaint was not to give precise instructions to the district attorneys, but rather to send them an order in quite general terms:

See that the passage of regular trains carrying United States mails in the usual and ordinary way, as contemplated by the act of Congress and directed by the Postmaster-General, is not obstructed. Procure warrants or

95. The official correspondence on the Pullman strike is gathered in 1896 ATT'Y GEN. ANn. REp. Apr. [hereinafter cited 1896 Appendix]. For a systematic account, see LindSex, The Pullatan Strike (1942).

96. 1893 ATT'Y GEN. ANN. REP. at xxvii-xxviii. The cases Olney referred to are United States v. Workingmen's Amalgamated Council, 54 Fed. 994 (C.C.E.D. La.), aff'd, 57 Fed. 85 (5th Cir. 1893), and Waterhouse v. Comer, 55 Fed. 149 (C.C.W.D. Ga. 1893).

97. Letter from Olney to Alexander, D.A., N.D.N.Y., May 12, 1893, D.J. Instr. Bk. No. 30, at 71, in Cummings \& MoFarLand, Federal Justice 438 (1937). 
any other available process from United States courts against any and all persons engaged in such obstruction and direct marshal to execute the same by such number of deputies or such posse as may be necessary. ${ }^{98}$

Two days later, however, he particularly reminded Milchrist, the district attorney in Chicago, which was the center of the tumult, of a series of precedents that he should consider in applying for a restraining order. The cases Olney listed clearly indicate that he did not have the Sherman Act in mind. All of the precedents tended to demonstrate that federal courts could restrain the strikers without invoking the authority of any statute; two of them involved the Sherman Act, but in both cases it was extraneous to the court's theory; and, most significantly, the Workingmen's Council case was conspicuous by its absence.99 Milchrist clearly saw the point and answered that he would apply for an injunction on the authority of the Interstate Commerce Act. ${ }^{100}$ During the next

98. Telegram from Olney to Milchrist, June 28, 1894, in 1896 Appendix 55. The text of the order is similar to that of the directive Olney issued when western counterparts of Coxey's Army seized trains in April 1894; this suggests that Olney contemplated using the same remedies, which in the former case had not included any action under the Sherman Act. See Cunnings \& McFarland, Federal Justice 439 (1937); McMurray, CoXey's ArMy ch. 10 (1929).

99. See Telegram from Olney to Milchrist, June 30, 1894, in 1896 Appendix 57. Olney cited: United States v. Clark, 25 Fed. Cas. 443 (No. 14805) (E.D. Pa. 1877) ; United States v. Claypool, 14 Fed. 127 (W.D. Mo. 1882); United States v. Kirby, 74 U.S. (7 Wall.) 482 (1868) ; Toledo, A.A. \& N.M. Ry. v. Pennsylvania Co., 54 Fed. 730 (C.C. N.D. Ohio 1893) ; Blindell v. Hagan, 54 Fed. 40 (C.C.E.D. La.), aff'd, 56 Fed. 696 [miscited in Olney's telegram as 596] (5th Cir. 1893); Waterhouse v. Comer, 55 Fed. 149 (C.C.W.D. Ga. 1893) ; Farmers' Loan \& Trust Co. v. Northern Pac. R.R., 60 Fed. 803 (C.C.E.D. Wis. 1894) [miscited as 16 Fed. 803].

In the first three of these cases, courts ruled on indictments for obstructing the mail in contravention of REv. STAT. $\$ 3995$ (1875) (now 18 U.S.C. $\$ 1701$ (1952)). In the Toledo Ry. case, the court enjoined a strike on the authority of the Interstate Commerce Act, 24 Stat. 379 (1S87), 49 U.S.C. $\$$ 1-22 (1952). The Blindell case held that a court of equity could enjoin a strike if the threatened damages were irremediable at law. And Waterhouse and Farmers' Loan were precedents for the proposition that a court of equity could enjoin a strike directed against property being administered by a receiver under its superintendence. The Sherman Act was mentioned in the Blindell case, but the court there held the act inapplicable since it did not authorize private parties to sue for injunctions. In the Watcrhouse case, the Sherman Act and the Interstate Commerce Act were said to make strikes against interstate railroads illegal, but this view was obiter; the court was able to base its objection to rule 12 of the Brotherhood of Locomotive Engineers, which authorized secondary boycotts, on a broader principle:

[I]f there were no statutory enactments upon the subject, no court of equity could justifiably direct its receiver to enter into a contract with a body of men who hold themselves bound to repudiate their contract, and disregard a grave public duty, because of real or alleged grievances, which some other person or corporation, not a party to the contract, inflicts or is alleged to inflict, not upon a party to the contract, but upon somebody else.

Waterhouse v. Comer, 55 Fed. 149, 158 (C.C.W.D. Ga. 1893).

100. Telegram from Milchrist to Olney, June 30, 1894, in 1896 Appendix 57. 
few days, however, he became persuaded that the Interstate Commerce Act did not apply to laborers. He therefore asked permission to proceed on the authority of the Sherman Act and the Workingmen's Council case, and added an alarming comment on the situation: "The general paralysis of interstate and general business warrants this course. Very little mail and no freight moving. Marshal is using all his force now owing to mob and obstruction of tracks ... . His force is clearly inadequate." 101

Milchrist's view of the strike as a critical emergency was widespread; the news of disorder, frightening enough in itself, awakened memories of the succession of violent incidents over the past few years-the Haymarket riot, the Coeur d'Alene troubles, the Homestead strike, and the march of Coxey's Army-incidents which, like the present strike, seemed to verge on armed insurrection and aroused the anger of responsible men. William Howard Taft's views were not at all extreme when he wrote to his wife:

The situation in Chicago is very alarming and distressing and until they have had much bloodletting, it will not be better. The situation is complicated by the demagogues and populists ... who are continually encouraging resistance to federal authority. Word comes tonight that thirty men have been killed by the federal troops. Though it is a bloody business, everybody hopes that it is true. ${ }^{102}$

In circumstances like these, an Attorney General could not insist too firmly on his own view of the act's proper functions. Besides, the district attorneys were primarily responsible for getting the indictments, and Olney could not tie their hands by denying them the use of a statute which, by judicial construction, was applicable. Hence, a few days before Milchrist's request, when Charles Garter, district attorney in San Francisco, expressed his belief that the strike violated the Sherman Act, Olney had answered: "Act upon your view of the law, which is certainly sustained by adjudications so far as they have gone." 103 Although the tone of the message suggests that Olney did not share that view of the law or consider the decisions authoritative, he evidently felt that the time was not one for cavil. Presumably for the same reason, when

101. Letter from Milchrist to Olney, July 1, 1894, in 1896 Appendrx 60-61. Milchrist prepared the bill after consulting with the railroads' attorneys, and Thorelli, who exaggerates Walker's influence on the proceedings, makes the very doubtful suggestion that the conference was "presumably instigated by Walker himself." THORELLI, THE FEDERAL Antitrust Policy 390 (1954). As evidence to the contrary, Walker was not in Chicago during the early days of the strike and did not return until after the conference; moreover, Milchrist had been conferring with the railroad attorneys several days before Walker was appointed special counsel. See Letter from Milchrist to Olney, June 30, 1894; Telegram from Milchrist to Olney, July 2, 1894; Telegram from Walker to Olney, July 2, 1894; all in 1896 ApPENDIX 57-58, 63.

102. Letter from W. H. Taft to Helen H. Taft, July 7, 1894, in 1 Pringle, LIFE AND Trares of William Howard Taft 128 (1939).

103. Telegram from Garter to Olney, June 28, 1894; Telegram from Olney to Garter, June 29, 1894; both in 1896 APPENDIX 17-18. 
Milchrist requested similar authority, Olney approved, and soon was recommending that other district attorneys follow Milchrist's successful example. ${ }^{\mathbf{1 0 4}}$

Olney's reluctance to base the injunction on the Sherman Act is indicated also by his suggestion to Walker in September, when the strike was over and Debs and other union officers were being tried for violating the injunction, that he need not rest the Government's case solely on the act. Courts of equity, he argued, had always exercised the power to enjoin the obstruction of public highways at the instance of the Government, and railroads were in effect public highways. ${ }^{105}$ Walker used this argument in addition to the one founded on the Sherman Act, and Judge Woods of the circuit court in Chicago sustained the injunction on both grounds. ${ }^{100}$ The following spring, when the case came before the Supreme Court, Olney gave Assistant Attorney General Edward B. Whitney the responsibility for preparing the brief and presenting the discussion in so far as it bore on the Sherman Act. ${ }^{107} \mathrm{He}$ himself maintained in his oral argument that, though the act did apply, "under all the circumstances of this case, it seems to me quite inadvisable that the jurisdiction of the court below should be thought to turn upon the Government's technical relation to the mails and the mail bags, or should appear to depend upon the novel provisions of an experimental piece of legislation like the Act of 1890."108 Reverting to the theory he had implied in his first instructions to Milchrist and had more recently suggested to Walker, he maintained that federal courts had broad powers to restrain interference with interstate commerce and thus needed no special statute to support them. The Supreme Court may have accepted this argument; in any event, it apparently decided the case without relying on the Sherman Act. ${ }^{109}$

\section{Olney's Policy After the Pullman Strike}

Olney authorized no other Sherman Act cases. During the Pullman strike, District Attorney George J. Denis at Los Angeles took the unusual step of serving an injunction on officials of the Southern Pacific Railroad in order to force them, as he said, "to move mails and interstate commerce, which they can do, but are afraid of losing their own men after the strike is quelled."110 About a week later, Denis and his special assistant, Joseph Call, reported to Olney that the strike was over in their district and that the strikers were "fall-

104. See, e.g., Telegram from Olney to Garter, D.A., N.D. Cal., July 2, 1894; Telegram from Olney to Cleveland, D.A., S.D. Ohio, July 3, 1894; both in 1896 Appendix 20, 171 and passin.

105. Letter from Olney to Walker, Sept. 24, 1894, in Lindsey, The PulinaAn Strike 289-20 (1942).

106. United States v. Debs, 64 Fed. 724 (C.C.N.D. Ill. 1894) (finding the defendants guilty of contempt).

107. JAMES, op. cit. supra note 87 , at 57.

108. Oral Argument of Attorney General, p. 2, In re Debs, 158 U.S. 564 (1895).

109. In re Debs, 158 U.S. 564 (argued March 25, 26, 1895; decided May 27, 1895).

110. Telegram from Denis to Olney, July 8, 1894, in 1896 Appendix 29. 
ing over each other to get back to work"; but having begun with assurance that everything was under control, they continued: "The situation, in our opinion, demands enforcement of act of July 2,1890, against unlawful combines of railroads and transportation companies, and we respectfully suggest bringing suit in name of Government to enforce that law.'111 Olney, thinking that the "situation" was a continued refusal of the Southern Pacific to run trains, authorized "any appropriate suits"; he soon discovered, however, that Denis and Call had filed suit to dissolve the Southern Pacific Company, which they alleged was a corporation comprising thirty-five railroads combined to restrain interstate commerce. ${ }^{112}$ Olney immediately assured the newspapers that this was not at all what he had meant to authorize. ${ }^{113}$ Informed by newsmen of Olney's comment, Denis stated that, considering the authorization of the Attorney General and the notoriety of the Southern Pacific, he and Call, "could see no more appropriate time to enforce this all-but-forgotten law. ... I am absolutely sure that [the Attorney General] . . . will approve of my course when he has an opportunity to read my report of facts to him."114 Call wrote to Olney in a similar vein, urging that the strike had left "slumbering: discontent," and that nothing had "done so much to alienate the people of the Pacific Coast from the Government of the United States as the oppressions of [the Southern Pacific] monopoly upon these people."115 Olney still replied that the complaint was indefensible and must be dismissed. The Sherman Act was "prospective in its operation; could not, if it undertook to do so, make crimes out of transactions long passed and not criminal when they occurred." $\mathrm{He}$ made one concession. Denis might, "after acquiring adequate knowledge of the facts and making careful study of the law and decided cases," prepare a new bill, but he must submit it to the Department before filing it in court. ${ }^{113}$ Denis countered by arguing that the question of retroactive application of the law did not arise, since his bill in equity sought not to punish the defendants for their past actions but to invalidate certain of their present contracts. ${ }^{117}$ Nevertheless, he dismissed the bill ${ }^{118}$ and did not prepare a new one.

On another occasion, R. B. Glenn, the district attorney in Winston, ${ }^{119}$ North Carolina, reported a "terrible clamor" for prosecuting the American Tobacco Company and submitted for approval a proposed indictment. At first, Olney

111. Telegram from Denis and Call to Olney, July 14, 1894, in 1896 Appendrx 33.

112. Telegram from Olney to Denis, July 14, 1894, in 1896 Appendix 33. The suit was filed on July 16; according to Denis, Olney heard about it from complaining officials of the Southern Pacific. See N.Y. Times, July 19, 1894, p. 5, col. 4.

113. Dispatch from Washington, dated July 17, 1894, reported in N.Y. Times, Aug. 4, 1894 , p. 4 , cols. $4-5$.

114. N.Y. Times, July 19,1894 , p. 5 , col. 4.

115. Letter from Call to Olney, July 18, 1895, in 1896 Appendx 34-35.

1.16. Telegram from Olney to Denis, Aug. 1, 1894, in 1896 Appendrx 36.

117. Letter from Denis to Olney, Aug. 2, 1894, in 1896 Appendix 37-40.

118. Telegram from Denis to Olney, Aug. 4, 1894, in 1896 Appendix 40.

119. Later, Winston-Salem. The towns of Winston and Salem were consolidated in 1913. 
thought it best to delay for a while; "it would seem wholly unwise not to wait until the Supreme Court is heard from." After the Court decided the Sugar case, Glenn continued to urge action, maintaining that his case against the tobacco trust was much stronger; but Olney considered the question closed. ${ }^{120}$

\section{The Policy of Attorney General Judson Harmon}

In June of 1895, Olney became Secretary of State and was succeeded as Attorney General by Judson Harmon. The basic fact controlling antitrust policy remained the same: the Sugar Trust decision stood as a great obstacle to further prosecution. Harmon recognized that, according to the decision, trusts, "although they may unlawfully control production and prices of articles in general use, cannot be reached under this law merely because they are combinations and monopolies, nor because they may engage in interstate commerce as one of the incidents of their business." 121 This principle, he felt, largely tied his hands, but not altogether, for the act might yet be held applicable to combinations the heart of whose business was in interstate commerce. Certainly, it would be worth testing the possibility by an appeal. Soon after arriving in Washington, therefore, he looked through the docket to select, in his words, "a number of cases to argue myself." He found the Trans-Missouri Freight Association case, in which the circuit court had held that the Sherman Act was inapplicable to railroads, and the court of appeals, without questioning the lower court judgment, had gratuitously added that the act did not prohibit an agreement regulating, but not suppressing, competition. The case had impressed Harmon a few months earlier when, in a private suit he was then conducting, it was cited as authority against him. He was convinced at once that the decision was incorrect, and decided as Attorney General to test his view in the Supreme Court. ${ }^{122}$

Before the Supreme Court heard the Trans-Missouri appeal, however, Harmon was forced to begin a new suit involving a similar railroad pool. Senator William Eaton Chandler of New Hampshire, who had become a vigorous antagonist of railroad abuses, wrote to Harmon in August 1895 to complain about an agreement that was then being negotiated among the leading eastern

120. Letters from Glenn to Olney, Aug. 6, 1894, Dec. 4, 1894, March 14, 1895; Letter from Olney to Glenn, Dec. 12, 1894; all in Thorelli, The Federal Aintrtrust Policy 338 (1954). Thorelli conveys the impression that Olney finally vetoed the project during a conference which took place "more than a year" after Glenn first raised the subject, that is, more than a year after August 6,1894 . Thorelli does not supply a more precise date for the conference but, certainly, if it was held on or after August 6,1895, Olney was not involved, for he resigned the attorney generalship on June 7, 1895.

121. 1895 ATt'y GEN. ANN. Rep. 13.

122. Letter from Farmon to Macfarlane, Jan. 2, 1896, D.J. Instr. Bk. No. 60, at 448. Harmon made the decision to appeal before August 24, 1895. See Ietter from Harmon to Chandler, Aug. 24, 1895, in Senate Committee on Interstate Commerce, Hearing in Relation to the Agrecment of the Joint Traffic Association, S. Doc. No. 64, 55th Cong., 1st Sess. 33 (1897) ; United States v. Trans-Missouri Freight Ass'n, 53 Fed. 440 (C.C.D. Kan. 1892), aff'd, 58 Fed. 58 (8th Cir. 1893), rev'd, 166 U.S. 290 (1897). 
railroads. The Joint Traffic Association which they proposed to form would establish uniform rates, allocate traffic, and distribute earnings; surely, wrote Chandler, the Attorney General should prevent the formation of "the most gigantic trust and combination the world has ever known."123 Harmon answered that proceedings against the Association, as he gathered from newspaper accounts, would raise the same questions as the Trans-Missouri case. "I presume," he continued, "that the present arrangement, whatever it is, has been carefully brought within the lines of the decision of Judge Sanborn in that case."124 Although Harmon was on firm ground in refusing to institute a new action until the appeal was settled, he failed to make his position clear to Chandler. Instead of carefully explaining his views and offering to investigate, he said only that the Association agreement was probably within the law and that, "until the pending case is decided and the law settled in the Supreme Court, it does not seem to me that there is anything for this Department to do in the matter." Chandler, having received a similar reply from the Interstate Commerce Commission, wrote to Harmon:

The promptitude with which you have assumed, in behalf of the railroad conspirators, that their coming trust combination is a successful violation of the criminal laws of the United States is only equaled by the celerity with which Commissioner Morrison has decided that the Interstate Commerce Commission knows nothing whatever about the notorious pooling agreement and cannot find out anything until it has gone into operation. ${ }^{120}$

Chandler spent the next few months reminding the President, Attorney General and Commission of the forthcoming iniquity, which, as he repeated with increasing anger, they were doing nothing to forestall, 126

In time, William Morrison, chairman of the ICC, began to investigate the matter. He asked railroad officials to inform him of their exact plans; after much prodding, they sent the completed agreement ${ }^{127}$-which arrived on December 24th, eight days before it was to become effective. On December 26th, Morrison officially requested Harmon to institute proceedings against the Association under the Interstate Commerce Act: "This contract, agreement, or arrangement is, we believe, in conflict with the Act to regulate commerce and

123. Letter from Chandler to Harmon, Aug. 19, 1895, referred to in Letter from Chandler to McKenna, March 27, 1897, D.J. File 759-1887.

124. Letter from Harmon to Chandler, Aug. 24, 1895, in Senate Committee on Interstate Commerce, supra note 122 , at 33.

125. Letter from Chandler to Harmon, in Richardson, Wirlians E. ChandLer, RePUBLICAN 497 (1940). Although Richardson does not give the date, the letter is probably the one sent on August 30,1895, and referred to in Letter from Chandler to McKenna, March 27, 1897, D.J. File 759-1887.

126. The voluminous correspondence between Chandler and the ICC is reprinted in Letter of the Chairman of the I.C.C. Respecting an Agreement to Form a Joint Traffic Association, S. Doc. No. 39, 54th Cong., 1st Sess. (1895). RICHARdson, op. cit. supra note 125, at 497, cites five letters from Chandler to Cleveland, written between August 20 th and November 27 th.

127. See Letter of the Chairnan, supra note 126, at 16-19. 
cannot be carried into effect without violating the provisions of said Act."128 The ICC decision, seemingly reached in great haste during the day or two after the Commissioner first saw the articles of agreement, was actually not so spontaneous. A few days earlier, the Senate had passed a resolution directing the Commission to report on the entire matter. ${ }^{129}$ Morrison had submitted a report which emphasized the difficulties of taking any action, ${ }^{130}$ and had then discussed the matter with Harmon. Both of them apparently felt that senatorial pressure required some positive action on their part, no matter how doubtful the outcome. As Harmon wrote to the district attorney whom he put in charge of the case, "we both agreed that as this contract was undoubtedly drawn with great care by able counsel who doubtless believe that it is not contrary to law, the only proper course which can now be pursued is to test the lawfulness of the agreement by civil proceedings."131 In other words, since the administration was forced to take action against its better judgment, it would use the mildest process it could. Having reached this decision in consultation with Harmon, Morrison returned to his office and wrote the letter officially requesting enforcement, which all five commissioners formally approved. ${ }^{132}$ Harmon forwarded the ICC request to the district attorney in New York City, Wallace Macfarlane, with the suggestion that, though he himself had given the applicability of the Sherman Act "no thorough consideration," Macfarlane should look into the problem and report his conclusions. ${ }^{133}$

Subsequently, Macfarlane communicated his opinion that the Association agreement probably violated both the Interstate Commerce Act and the Sherman Act, but he wondered about the effect of the Trans-Missouri decision. ${ }^{134}$ Harmon agreed that the decision might cause trouble, but observed that it was being appealed and that nothing more could be done. "If, on the strength of it, the other side succeeded in defeating an application for a preliminary injunction the responsibility will be on the court and not on us ...."135 The suit was authorized, and the bill was filed on January 9, 1896. The proceedings were delayed, however, when all but two of the judges in the circuit disqualified themselves because they owned stock or bonds of the defendant railroads. ${ }^{136}$ The case was finally heard in April, the court deciding both that the Government had no power under the Interstate Commerce Act to restrain the railroads' agreement, and that their agreement, according to the Trans-Missouri

128. Letter from Morrison to Harmon, Dec. 26, 1895, D.J. File 759-87, in Letter of the Chairman, supra note 126, pt. 2, at 1 (where, however, the date is erroneously given as Dec. 27th).

129. 28 CoNG. REC. 253-54 (1895).

130. Letter of the Chairman, supra note 126.

131. Letter from Harmon to Macfarlane, D.A., S.D.N.Y., Dec. 27, 1895, D.J. Instr. Bk. No. 60 , at 344 .

132. Senate Committee on Interstate Commerce, supra note 122 , at 24.

133. Letter from Harmon to Macfarlane, Dec. 27, 1895, D.J. Instr. Bk. No. 60, at 344.

134. Letter from Maciarlane to Harmon, Dec. 31, 1895, D.J. File 18467-1895.

135. Letter from Harmon to Macfarlane, Jan. 2, 1896, D.J. Instr. Bk. No. 60, at 448.

136. Senate Committee on Interstate Commerce, supra note 122, at 4-6. 
decision, did not violate the Sherman Act. ${ }^{137}$ Macfarlane planned to ask the court of appeals simply to affirm the decision formally, in order to avoid unnecessary labor and delay in bringing the case before the Supreme Court. ${ }^{138}$ But since the members of the Senate Committee on Interstate Commerce were highly displeased that the Government should, as they thought, practically confess the weakness of its position, the case was eventually argued before the court of appeals, which, in a memorandum decision, immediately affirmed the lower court. ${ }^{139}$ The Joint Traffic case came before the Supreme Court in March 1897, just before that Court published its opinion in Trans-Missouri..$^{140}$

In the meantime, although the Trans-Missouri decisions obstructed attacks on railroad pools and the Sugar Trust decision impeded action against manufacturing monopolies, the Attorney General could still feel free to operate against combinations "in restraint of trade." ${ }^{141}$ An indictment brought against a combination of coal merchants in Salt Lake City had the easy success that it seems was specially ordained for actions of this sort from the Jellico Moututain Coal case onward. ${ }^{142}$ An injunction was sought against livestock dealers who had formed the Kansas City Live-Stock Exchange, and this too was successful in the lower court. ${ }^{143}$ Finally, at the urging of James Bible, district attorney at Chattanooga, Harmon authorized a suit against a combination of manufacturers of cast-iron pipe. ${ }^{144}$ His response to Bible on this occasion shows clearly the lines of his policy. After apologizing for delay in answering, he wrote:

I have no objection whatever to your proceeding against the people who are engaged in operating the pipe trust, but, on the contrary, highly approve such action-if you can find the proof to make it successful. The way the law has been construed, especially by Judge Jackson [in] in re Greene, and by the Supreme Court in U.S. vs. Knight, has made it pretty hard to accomplish anything.... I leave the whole matter to your own judgment, with full authority and discretion, only I would be careful not to shoot until I was sure of my aim. ${ }^{145}$

137. United States v. Joint Traffic Ass'n, 76 Fed. 895 (C.C.S.D.N.Y. 1896), aff'd mem., 89 Fed. 1020 (2d Cir. 1897), rev'd, 171 U.S. 505 (1898).

138. Senate Committee on Interstate Commerce, supra note 122, at 12-13.

139. Ibid. The case was argued on March 18-19, 1897. See N.Y. Times, March 19, 1897, p. 12, col. 2; id., March 20, 1897, p. 12, col. 1. The memorandum decision, United States v. Joint Traffic Ass'n, 89 Fed. 1020 (2d Cir. 1897), rev'd, 171 U.S. 505 (1898), was published March 19, 1897.

140. United States v. Trans-Missouri Freight Ass'n, 166 U.S. 290 (1897).

141. See Sherman Act, $\$ 1,26$ Stat. 209 (1890), as amended, 15 U.S.C. $\$ 1$ (1952).

142. United States v. Moore, C.C.D. Utah, Nov. 1896 (indictment, under $\$ 3$ of the act, returned Nov. 4, 1895; defendants found guilty and Moore fined), rev'd, 85 Fed. 465 (8th Cir. 1898) (holding that the circuit court no longer had jurisdiction after Jan. 4, 1896 , when Utah was admitted to the Union).

143. United States v. Hopkins, 82 Fed. 529 (C.C.D. Kan. 1897) (bill filed Dec. 31, 1896). On appeal, 84 Fed. 1018 (8th Cir. 1897), the case was certified to the Supreme Court, which reversed the decree. 171 U.S. 578 (1898).

144. United States v. Addyston Pipe \& Steel Co., 78 Fed. 712 (C.C.E.D. Tenn. 1897), rev'd, 85 Fed. 271. (6th Cir. 1898), aff'd, 175 U.S. 211 (1899).

145. Letter from Harmon to Bible, Dec. 2, 1896, D.J. Instr. Bk. No. 74, at 573. 
The caution which Harmon advocated and practiced eventually yielded a rich harvest. The results began to appear soon after the Cleveland administration left office in March 1897. Less than three weeks later, the Supreme Court overruled the Trans-Missouri decision, and perpetually enjoined the operation of the pool. ${ }^{140}$ Harmon proudly claimed the decision as a personal victory, ${ }^{147}$ while railroad companies, surprised and disconcerted, quickly broke away from the various associations that they had come to consider normal facilities of their business. ${ }^{148}$ The Court's subsequent decision that the Joint Traffic Association was illegal came as something of an anticlimax. ${ }^{149}$ Early in 1898, the Sixth Circuit Court of Appeals, per Judge William Howard Taft, issued a perpetual injunction against the defendants in the Addyston Pipe case. ${ }^{150}$ What little Harmon had done had turned out exceedingly well.

In 1896, however, when Cleveland was summing up the achievements of his administration, these successes were not foreseen. It therefore seemed necessary to offer excuses for a poor record. Accordingly, the President's last annual message contained a passage, closely following a memorandum prepared by Olney, which asserted that the antitrust laws "thus far have proved ineffective, not because of any lack of disposition or attempt to enforce them, but simply because the laws themselves as interpreted by the courts do not reach the difficulty." Further legislation might help, the message suggested, but perhaps any federal law would encounter the same constitutional impediment, and the problem might ultimately be solved only if the states exercised their powers also. 161

Harmon offered a rather different explanation. Although he, too, was bound to notice the obstacles raised by adverse decisions, he believed some of these could be overcome if Congress would amend the act. It ought to prevent unlawful combinations from shipping their goods among the states, define "monopoly" and "restraint of trade" more precisely, prevent witnesses from refusing to testify on grounds of self-incrimination, and add as a rule of evidence that the merging of competitors would, prima facie, demonstrate an attempt to monopolize. Finally, the chief administrative problem, the one to which Harmon referred repeatedly throughout his report, was the difficulty of collecting evidence. "If the Department of Justice is expected to conduct investigations of alleged violations ... it must be provided with a liberal appropriation and a force properly selected and organized. The present appropriation for the detection of crimes and offenses is very small, and the time of the examiners is fully occupied by the present important duties assigned to them." He added that the work should be done by a special agency outside the Department of

146. United States v. Trans-Missouri Freight Ass'n, 166 U.S. 290 (1897).

147. See N.Y. Times, March 25, 1897, p. 5, col. 1.

148. N.Y. Times, March 24, 1897, p. 12, col. 2; id., March 25, 1897, p. 5, col. 1.

149. United States v. Joint Traffic Ass'n, 171 U.S. 505 (1898).

150. United States v. Addyston Pipe \& Steel Co., 85 Fed. 271 (6th Cir. 1898), aff'd, 175 U.S. 211 (1899), reversing 78 Fed. 712 (C.C.E.D. Tenn. 1897).

151. 9 Richardson, Messages \& Papers of the Presidents 745 (1900). 
Justice. ${ }^{152}$ Several years passed, however, before Congress adopted his recommendation or made any attempt to correct this oversight in the original legislation.

\section{Disuse of the Sherman Act Under President McKinley}

The Republican platform of 1896, unlike those of the preceding two elections, said nothing about trusts, and the subsequent activities of President McKinley's Attorneys General suggest that the omission was not an oversight. A few weeks after the election, the newspapers published a letter-supposedly from Mark Hanna to an important Republican-saying that Bryan had found support among those who considered McKinley to be the candidate of the trusts and that, in order to "counteract the impression," McI inley would "assume a dignified attitude of antagonism" towards the combinations. ${ }^{153}$ Although Hanna immediately denounced the letter as spurious, it described reasonably well the course McKinley followed. In his inaugural address, he quoted phrases from the Republican platform of 1888 to show that the party had opposed trusts in the past. He promised that this policy would "be steadily pursued, both by the enforcement of the laws now in existence and the recommendation and support of such new statutes as may be necessary to carry it into effect."15.1

The Attorneys General who served under McKinley did virtually nothing to fulfill his pledge. Joseph McKenna, the most active, authorized two suits during his nine months in office. The first was a companion piece to Harmon's suit against the Kansas City livestock dealers and had been prepared in large part during the previous administration. ${ }^{155}$ The second suit was instituted through the efforts of a group of coal consumers and independent retailers in San Francisco who objected to a local combination of coal wholesalers. They hired an attorney who drafted a bill in the name of the Government; and, at the request of the local district attorney, McKenna approved the bill and appointed the private lawyer as special counsel to plead the case for the Government. ${ }^{156}$ Dealing with a set of facts which by now had become familiar, the court promptly granted an injunction against the combination. ${ }^{167}$

152. H.R. Doc. No. 234, 54th Cong., 1st Sess. (1896), reprinted in 1896 AtT'Y GeN. ANN. REP. 3-5.

153. N.Y. Times, Nov. 23, 1896, p. 4, col. 1.

154. 14 RrCeardson, op. cit. supra note 151, at 6240.

155. United States v. Anderson, C.C.W.D. Mo., bill filed June 7, 1897 (granting a temporary injunction), certified to Sup Ct., 82 Fed. 998 (8th Cir. 1897), rev'd, 171 U.S. 604 (1898). For the prior case, United States v. Hopkins, 82 Fed. 529 (C.C.D. Kan.), certified to Sup Ct., 84 Fed. 1018 (8th Cir. 1897), rev'd, 171 U.S. 578 (1898), see text accompanying note 143 supra.

156. Thorelli, The Feneral Antitrust Policy 405-06 (1954).

157. United States v. Coal Dealers' Ass'n, 1890-1918 Decrees \& Judgrents in FedERAL ANTI-Trust CASES 49 (C.C.N.D. Cal. 1897) (granting temporary injunction), comlbination decreed illegal, 85 Fed. 252 (C.C.N.D. Cal. 1898), perpetual injinction granted, 1890-1918 Decrees \& Judgaments in Federal Anti-Trust Cases 51 (C.C.N.D. Cal. 1899). 
Even these rather passive efforts exceeded those made by McKenna's successor. John W. Griggs was remarkable for the assiduity with which, during his three years in office, he declined every opportunity except one for enforcing the Sherman Act. To George Rice, who continued to urge that his ancient enemy, the Standard Oil Company, ought to be prosecuted under the Sherman Act, Griggs replied that there was nothing in Rice's letter to indicate that the business "of the alleged combination against which you complained, is of an interstate character."158 To another correspondent who suggested a suit against the beef trust, Griggs answered that he "must avoid entering upon a discussion with a gentleman who takes six pages of typewritten legal-cap to express his views." 150 The Solicitor General, John K. Richards, to whom Griggs delegated much of the antitrust work, followed a rather similar course. He allowed a district attorney in Galveston to investigate an alleged shipping trust, but refused the attorney's request for permission to sue. And when a private complainant suggested a suit against the United Fruit Company, Richards indicated that the Department would not proceed unless presented with all the necessary evidence. ${ }^{160}$

In explaining his failure to act, Griggs never tired of referring to the Sugar Trust decision. In an annual report he explained that the Department, when considering a complaint, was "governed only by a sincere desire to enforce the law as it exists and to avoid subjecting the Government to useless expense and the law officers of the Government to humiliating defeat by bringing actions where there was a clear want of jurisdiction under the well-defined limits of Federal jurisdiction so clearly laid down by the Supreme Court in cases already decided."'161 That he so completely overlooked the possibilities of building an active enforcement program on the recent and favorable decisions in the Trans-Missouri, Joint Traffic and Addyston Pipe cases, indicates that what Harmon considered an impediment Griggs used as an opportune buffer. ${ }^{162}$

Meanwhile, a great series of mergers was creating more and larger combinations than were formed during the years between 1887 and 1890. The depression that began in 1893 was followed after 1897 by exceptional prosperity, and the unusually active market for securities provided rewarding opportunities for the professional promoters who exploited the profits to be had from organizing new monopolies and reinforcing old ones. The wave of consolidations began in earnest during 1898, though for a while the Spanish-American War diverted attention from it. In the following year, the movement reached

158. Letter from Griggs to Rice, March 14, 1899, D.J. Misc. Bk. No. 36, at 469, in Thoreiti, The Federal Antitrust Policy 408 n.192 (1954).

159. Letter from Griggs to Cooke, Sept. 21, 1899, D.J. Misc. Bk. No. 39, at 216, in Thoreli, The Federal Antitrust Policy 409 n.193 (1954).

160. Thorelli, The Federal Antitrust Policy 407 n.188 (1954).

161. 1899 AtT'y Gen. ANn. Rep. 29.

162. The only antitrust action initiated by Griggs, United States ex rel. Griggs v. Chesapeake \& O. Fuel Co., 105 Fed. 93 (C.C.S.D. Ohio 1900), was affirmed, 1.15 Fed. 610 (6th Cir. 1902). 
a peak and, according to a contemporary estimate, produced eighty-seven new consolidations, each capitalized at an average of over twenty million dollars. ${ }^{103}$ Newspapers, civic leaders and reformers, lawyers, economists and bankers suddenly took notice of this remarkable phenomenon and of the evils it threatened. Special conferences were organized in Chicago by the Civic Federation and in St. Louis by the governors and attorneys general of the states; addresses were presented at conventions of various bar associations, at the American Economic Association meetings, at the International Commercial Congress, and at People's Institutes throughout the country; the United States Industrial Commission, a federal agency created to study economic conditions, collected evidence on the situation and its presumed causes. By the end of the year, President McKinley himself broke a three-year silence about trusts and, though he did not suggest that more vigorous efforts be made to enforce the existing law, observed that the new combinations were "justly provoking public discussion, and should early claim the attention of Congress."104 Still, Griggs was quite unmoved. When asked why he did not bring suits against the new combinations, he answered only: "As a matter of fact all the companies which you refer to as now organizing for the purpose of securing complete or partial monopoly of different branches of manufacture, are similar to the sugar combination and are not within the jurisdiction of the federal courts." 165

Whatever their thoughts in 1896 , the Republican Party managers could not overlook the need for an antitrust plank during the campaign of 1900 . The platform statement, which Hanna himself composed, constituted the first party endorsement of the distinction between "good" and "bad" combinations, a distinction which congressmen had often made during the debate on Senator Sherman's antitrust bills but which was not adopted as an explicit guide to enforcement policy until after Theodore Roosevelt became President. The Republican pledge read:

We recognize the necessity and propriety of the honest cooperation of capital to meet new business conditions, and especially to extend our rapidly increasing foreign trade ; but we condemn all conspiracies and combinations intended to restrict business, to create monopolies, to limit production, or to control prices, and favor such legislation as will effectively restrain and prevent all such abuses, protect and promote competition.

163. Conant, Industrial Consolidations in the United States, 7 PuBlications of the American Statistical Ass'n 207, 218 (1901). Conant's estimates are borne out in general by more recent investigations; see Markham, Survey of the Evidence and Findings on Mergers, in National Bureau of Economic Research, Business Concentrations AND Price Policy 141 (1955).

164. McKinley, Third Annual Message, Dec. 5, 1899, in 14 Richardson, op. cit. supra note 151 , at 6360 .

165. Letter from Griggs to J. C. Bowadaile, March 21, 1899, in N.Y. Herald, March 22,1899 , p. 5 , col. 6 , and Thorelli, The Federal Antitrust Policy 409 n.195 (1954). See also Letter from Griggs to Pingree, Gov. of Michigan, in N.I. Times, Sept. 27, 1899, p. 14, col. 2 . 
and secure the rights of producers, laborers, and all who are engaged in industry and commerce. ${ }^{166}$

But this change in the party's program did not bring with it any change in practice during the six months of McKinley's second term. His new Attorney General, Philander C. Knox, did nothing that foreshadowed his later vigor in enforcing the act, and McKinley showed no sign of increased interest. By September of 1901, when McKinley was assassinated and Theodore Roosevelt took the oath of office, the Sherman Act had gone practically unenforced for five years.

The explanation that Griggs and others offered concerning the weakness of the Sherman Act was accepted by many critics who, therefore, attributed the poverty of antitrust policy before 1903 to the Sugar Trust decision and, more generally, to the supposed hostility of judges. But judges cannot, without declaring a law unconstitutional, absolutely prevent its enforcement. For judicial action to have this effect, the Attorney General must consider himself constrained by the judges' interpretations. If he believes that the courts have enervated a statute, as Olney had reason to believe before, and especially after, the Sugar Trust decision, he may well refrain from using it. If, on the other hand, he wishes to expand its scope, he may, even in the face of obstacles, test the precedents by appeal and explore untried aspects of the law, as Harmon did. But once the courts have handed down a series of decisions which suggest that the statute is, after all, applicable in some degree, a striking absence of enforcement must be attributed to government policy. What was prudence and reasonable self-restraint before the Supreme Court decided the Trans-Missouri, Joint Traffic, and Addyston Pipe cases was bound to seem like laxity afterwards.

There may or may not have been adequate reasons for the McKinley administration's failure to use the act after 1899. In any event, only the two or three years of inactivity following that date can plausibly be attacked in the way that the entire early administration of the act so often has been. It may be that when Edmunds wrote in 1903, "What is needed is not, so much, more legislation as competent and earnest administration of the laws that exist," he was on firmer ground than when he made a similar statement in 1892. Perhaps even in 1903, however, he weakened his position by adding a vital qualification. The Sherman Act could control the trusts, he said, "if the officers of the Government having charge of the enforcement of law understand their duty and are willing to do it, being, of course, supplied with sufficient means to put it into force."107

166. McKee, National Conventions and Platforms 342-43 (4th ed. 1901) ; Croly, Marcus Alonzo HanNa 306-07 (1912).

167. Letter from Edmunds to Sleicher, Jan. 2, 1903, in 36 CoNg. Rec. 1901 (1903). 


\section{THE YALE LAW JOURNAL}

\begin{tabular}{lll}
\hline VoLUMe 68 & JANUARY 1959 & Nunrber 3 \\
\hline
\end{tabular}

Mitchet J. Ezer

BURT W. GRIFFIN JEROLD H. ISRAEL Michaet J. Nassau

AlaN L. Wurtzer

Note and Comment Editors

MatThew T. Adams

David Albenda

Alan Appet.baun

ROBERT I. BARD

Arthur J. Berk

Noratan A. Bikales

Benjamin W. Boley

Richard A. Brady

Peter D. Caldwell

James M. Edwards

Eliezer Ereta

David R. Evans

J. EDWard Fowler

Thonas N. Fromock

David Goldberg
Sydney M. Cone, III

Editor-in-Chief

Stuart B. Goldman

RuCHaRd S. HaRRISON

NEIL S. HeCHT

Reuben L. Hedlund

JacoB W. Heller

Alan M. Hoffrian

Benjanin T. HopkINs, II

Williadr A. Kass

ARoN KatZ

N. Herschel Koblenz

Eugene I. Lambert

J. D. LAMiBERT

IRVING I. LESNICK

JoFN C. McGuIRE
ROBERT J. ENGELATAN

JoHN K. MCNULTY

Article and Book

Reviez Editors

T. Cecir. Wray, JR. Managing Editor

Frenerick W. McNabe, JR. Stephen MaNN

Bruce Montgomery

Jerrold L. Morgulas

SAMUUEL MYyers

J. AlExANDER ONDERDONK

Alan D. PEKEL NER

Charles J. Prentiss

Herbert Schreiber

Barry Sidman

RTCHARD LAUder SutToN

Colin C. TaIt

Gilbert Paul Verbit

HeRbert S. WANDER

DoNAID P. WEFER
Marte McMahon

Business Secretary
David Berliner

Business Manager

\section{CONTRIBUTORS TO THIS ISSUE}

Thurman ARnold. A.B. 1911, Princeton University; LL.B. 1914, Harvard University. Professor of Law, Yale Law School, 1931-1938; Assistant Attorney General of the United States, in charge of antitrust, 1938-1943; Associate Justice, United States Court of Appeals for the District of Columbia, 1943-1945. Member, firm of Arnold, Fortas \& Porter.

FRED Rodelt. A.B. 1926, Haverford College; LL.B. 1931, Yale University. Author of books on constitutional law and the judicial process; contributor to national magazines. Professor of Law, Yale Law School.

Abranam S. Gondstern. B.B.A. 1946, City College of New York; LL.B. 1949, Yale University. Member, firm of Donohue \& Kaufmann, Washington, D.C., 1951-1956. Associate Professor of Law, Yale Law School.

Winctanr Letwin. B.A. 1943, Ph.D. 1951, University of Chicago. Post-doctoral Fellow, Economics Department, University of Chicago, 1951-1952. Research Assistant, University of Chicago Law School, 1953-1955. Associate Professor of Industrial History, School of Industrial Managament, Massachusetts Institute of Technology. 